\title{
Subjective And Territorial Scope of confugium ad eCClesias AND CHRISTIAN IDEAS
}

\section{Introduction}

Beginnings of asylum (asylum, ius asyli, confugium) ${ }^{1}$ in ancient Rome date back to Romulus times:

Livius, Ad urbe condita 1,8: Deinde ne vana urbis magnitudo esset, adiciendae multitudinis causa vetere consilio condentium urbes, qui obscuram atque humilem conciendo ad se multitudinem natam e terra sibi prolem ementiebantur, locum qui nunc saeptus descendentibus inter duos lucos est asylum aperit. Eo ex finitimis populis turba omnis sine discrimine, liber an servus esset, avida novarum rerum perfugit, idque primum ad coeptam magnitudinem roboris fuit.

According to Livius, he was to designate a place, to which people (free ones and slaves) from neighbouring cities could take shelter. The purpose of such asylum was probably to increase the number of inhabitants.

* Dr. habil., Associate Professor; University of Rzeszów; e-mail: rskok@ur.edu.pl, ORCID ID: https:/ / orcid.org/0000-0003-2635-6462.

1 W. Ihne, The Asylum of Romulus, The Classical Museum. A Journal of Philology, and of Ancient History and Literature 1846, vol. 3, pp. 190-193; P.G. Caron, Asylum, in: Novissimo Digesto Italiano, vol. 1-2, ed. A. Azara, E. Eula, Torino 1957-1958, pp. 1036-1039; H.G. Heumann, E. Seckel, Handlexikon zu den Quellen des römischen Rechts, s.v. Asylum, Jena 1907 (reprint Graz 1958), p. 42; G. Grifò, Asilo, in: Enciclopedia del diritto, vol. 3, ed. F. Calasso, [Milano] 1958, pp. 191-197; P. Stengel, Asylum, in: Thesaurus Linquae Latinae, vol. 2, Leipzig 1900-1906, pp. 990-991; J. Sondel, Stownik łacińsko-polski dla prawników i historyków, s.v. Asylum, Kraków 1997, p. 88. 
Initially, the right of asylum was sacred in ancient Rome, and its main place was found in temples. ${ }^{2}$

In the subsequent periods of the development of the Roman state, the asylum law continued to develop and was included in the norms of material law. In the republican period, there were no comprehensive legal regulations regarding ius asyli, although temple asylum was known. The Roman state did not recognise asylum guaranteed by other states, especially demanded the surrender of those who committed crimen.

Only during the empire there was legal regulation of asylum, two of its legal forms had been developed, in other words confugium ad statuas ${ }^{3}$ (asylum, escape to the monument to the emperor) and confugium ad ecclesias ${ }^{4}$ (church asylum).

2 Wiesław Mossakowski dealt with the issue of asylum in ancient Rome in Polish literature in his articles (idem, Karalność naruszenia azylu Kościoła w epoce cesarstwa rzymskiego, in: Kara śmierci w starożytnym Rzymie, ed. H. Kowalski, M. Kuryłowicz, Lublin 1996, pp. 101-107; idem, Z badań nad prawem azylu w starożytności chrześcijańskiej, Prawo Kanoniczne 1996, vol. 39, no. 1/2, pp. 199-204; idem, The Problems of the Temple Asylum Genesis in the Ancient Rome, Pomoerium. Studia et Commentarii ad Orbem Classicum Spectantia 1996, vol. 2, pp. 5-12; idem, Azyl kościelny a problem religii w późnym Cesarstwie Rzymskim, in: Profesorowi Janowi Kodrębskiemu in memoriam, ed. A. Pikulska-Robaszkiewicz, Łódź 2000, pp. 247-263) and monographs: idem, Azyl w późnym Cesarstwie Rzymskim (confugium ad statuas, confugium ad ecclesias), Torun 2000.

3 Das antike Asyl. Kultische Grundlagen, rechtliche Ausgestaltung und politische Funktion, ed. M. Dreher, Köln-Weimar 2003, pp. 107-127; P. Karlin-Hayter, Aréthas et le droit d'asile. A propos d'un article récent, Byzantion 1964, vol. 34, no. 2, pp. 613-617; C. Gioffredi, Ad statuas confugere, Studia et Documenta Historiae et Iuris 1946, vol. 12, pp. 187-191; M. Holleaux, Remarques sur les décrets des villes de Crète relatifs à l asylia de Téos, Klio 1913, vol. 13, pp. 137-157; F. v. Woeß, Aavגia [online], Zeitschrift der Savigny-Stiftung für Rechtsgeschichte: Romanistische Abteilung 1926, vol. 46, pp. 32-67, https://www.degruyter. com/view/j/zrgr.1926.46.issue-/zrgra.1926.46.1.32/zrgra.1926.46.1.32.xml?format=INT [access: 1.07.2020].

4 K. Burczak, Prawo azylu w ustawodawstwie synodów galijskich V-VII wieku, Lublin 2005, pp. 25-84; G. Franke, Das Kirchenasyl im Kontext sakraler Zufluchtnahmen der Antike. Historische Erscheinungsformen und theologische Implikationen in patristischer Zeit, Frankfurt am Main 2003; J. Śrutwa, Praktyka azylu kościelnego w ujęciu św. Augustyna, in: Chrześcijanie a życie publiczne w cesarstwie rzymskim III-IV w., ed. J. Śrutwa, Lublin 1988, pp. 66-68; H. Kulbat, Azyl kościelny. Studium prawno-historyczne, Łomża 1938; A.D. Manfredini, "Ad ecclesiam confugere", "ad statuas confugere" nell'età di Teodosio I, in: Atti dell'Accademia Romanistica Costantiniana, vol. 6. Convegno internazionale, ed. G. Crifò, Perugia 1986, pp. 39-58, https:/ /www.degruyter.com/view/j/zrgr.1988.105.issue-1/ zrgra.1988.105.1.915/zrgra.1988.105.1.915.xml [access: 30.06.2019]. 
Within the framework of that study there is no intention to present the right of asylum in its entirety, which has been the subject of many analyses, just to focus on answering the question, whether Christian ideas had an impact on the subjective and territorial scope confugium ad ecclesias, because after the Edict of Milan which took place in 313, Christianity, being able to worship publicly, began to have an impact on the consciousness of the inhabitants of the empire. The Church was conceived as an institution protecting the weak, persecuted and those in need. It also seems that the right of asylum has been enriched with some Christian elements, especially mercy (misericordia).

\section{Formation of confugium ad ecclesias}

As some researchers indicate, the first legal act, which granted Christian churches the right of asylum, were issued by Constantine the Great Acta Silvestri, as to the authenticity of which there are many well-founded doubts. ${ }^{5}$ It seems that the state was seeking legitimacy of asylum, which existed as a factual phenomenon and recognition of Christianity by Theodosius I as the imperial religion ${ }^{6}$ made church a place of shelter. On the one hand, confugium ad ecclesias, based on the sanctity of the place, referred to an earlier temple asylum. On the other hand, they tried to keep some difference, and not just because of the different nature of religion. Among others, the name asylum was replaced by the term confugium.

The first act that introduced church asylum to state legislation was the constitution of Emperor Theodosius established in 392:

C. Th. 9,45,1 (Imppp. Theodosius, Arcadius et Honorius aaa. Romulo comes sacrarum largitionum): Publicos debitores, si confugiendum ad ecclesias crediderint, aut ilico extrahi de latebris oportebit aut pro his ipsos, qui eos occultare probantur, episcopos exigi. Sciat igitur praecellens auctoritas tua neminem debitorum post hac a clericis defendendum aut per eos eius, quem defendendum esse crediderint, debitum esse solvendum.

5 Cf. K. Burczak, Prawo azylu..., p. 57 and further literature indicated there.

6 C. Th. 16,1,2; C. 1,1,1. 
The above-mentioned constitution was issued on 18 October 392 by Emperor Theodosius in Constantinople and addressed to Romulus who was the treasury manager (comes sacrarum largitionum). It was an act that sanctioned church asylum, which, like the imperial one, became a state institution. The above-mentioned act excluded public debtors until they paid their debts. For the first time wording confugium ad ecclesias was used for the designation of church asylum.

As K. Burczak emphasised, ${ }^{7}$ not only imperial constitutions played an important role in shaping the right of asylum after 313, but synodal legislation, which related to issues considering asylum law, had an impact, too. Since it was not the emperor's decision that made the temple a sanctuary, but the sanctity of the place. Imperial constitutions only sanctioned the legally existing state of affairs.

The first document in which bishops established the right of asylum for Christian churches was the canon 7 (8) of the synod in Sardica (Sofia), which took place in 342 or $344 .{ }^{8}$ In this canon, in the basic part, bishops forbade clerics to go to the imperial court under various pretexts, including the protection of the weaker, in order to make their own requests. However, in the passage cited below, Bishops wrote about church asylum:

[...] But I account it quite proper for a bishop to give assistance to one oppressed by some one, or to a widow suffering injustice, or, again, an orphan robbed of his estate, always provided that these persons have a just cause of petition. If, then, beloved brethren, this seems good to all, do ye decree that no bishop shall go to the imperial Court except those whom our most pious emperor may summon by his own letters. Yet since it often happens that persons condemned for their offences to deportation or banishment to an island, or who have received some sentence or other, beg for mercy and seek refuge with the Church [i.e., take sanctuary], such persons are not to be refused assistance, but pardon should be asked for them without delay and without hesitation. If this, then, is also your pleasure, do ye all vote assent. ${ }^{9}$

\footnotetext{
7 K. Burczak, Prawo azylu..., p. 65
}

8 Synod in Sofia (Ulpia Sardica) or Sofia in Bulgaria convened between 342 and 344 by Emperors Constans and Constantius II at the request of Pope Julius, who was mainly involved in Arianism, but he also devoted some attention to escaping to churches. Except that the canons of that synod did not become universally binding, they were binding only in the west of the empire, cf. A. Żurek, Wprowadzenie do Ojców Kościoła, Kraków 1993, pp. 75-78.

9 English translation of the Greek content of Canon 7 (online), http://www.documenta-catholica.eu/d_Concilia\%20-\%20The\%20First\%20Seven\%20Ecumenical\%20Councils\%20[History 
The content of that canon indicates that in the $4^{\text {th }}$ century shelter was sought in church. It seems that the adopted norm dictated that clergymen should help the escapees to church, based on the moral obligation to help the weak. In addition, the right to legal protection for fugitives resulted from the fact of staying in the place where the asylum law established by bishops was applicable. It may be argued that the norm of the canon in the material sense recognised asylum as a legal institution in church legislation. In the content of that canon written in Greek, however, the well-known Greek term ăavגia was not used, but instead the term

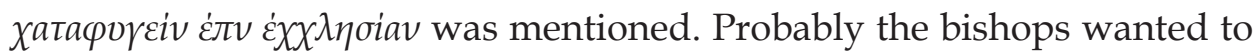
move away from the pagan idea of asylum, pointing to the Christian mer$\mathrm{cy}$, being the basis of church asylum, as an institution protecting the weak and the persecuted. ${ }^{10}$

The Canon 7(8) of the Synod in Sardica became the basis for the settlement of issues related to church asylum by imperial legislation. Except that there were no provisions in the canon that would prohibit the entry of state authorities and taking away fugitives. The help of bishops was to consist only of intercession with state authorities, that the asylum seeker should be protected by the Christian temple until the end of the trial. ${ }^{11}$

During the synod in Carthage in 399, the right of asylum was also discussed. African bishops wanted to obtain from the emperor the law to ban on the fugitives escaping from the church, who took shelter in the church while being involved in crime. ${ }^{12}$

The issues of church asylum also appeared during the synod session titled: "Under the Oak" nearby Chalcedon in 403. The literature sources describe the discussion between Bishop Isaac and John Chrysostom who is entitled to ius asyli, whether all who take shelter in church or only believers (differences as to the subject). However, they agreed to the extent (objective meaning) that the protective function resulted from the holy place. ${ }^{13}$

\footnotetext{
\%20and \%20Canons] \%20-\%20EN.pdf [access: 30.06.2019]; Polish translation of the Greek content of Canon 7 cf. Acta Synodalia, vol. 1, ed. A. Baron, H. Pietras, Kraków 2006, pp. 150-151.

10 Cf. K. Burczak, Prawo azylu..., pp. 66-71.

11 Cf. ibidem, p. 70, footnote 170 and further literature referring to the relationship between intercessio clergy and church asylum.

12 Dionysius Exiguus mentions about this synod, PL 67, vol. 193-223.

13 H. Kulbat, Azyl kościelny..., p. 20; W. Mossakowski, Azyl w późnym Cesarstwie
} Rzymskim..., p. 139. 
It seems that the bishops' pursuit of legal regulation of asylum has become the basis for the issuing of relevant constitutions by the emperors. In literature, the constitution of Theodosius from 431 (imperial law about refuge in temples) is regarded as the first positive recognition of church asylum by the Roman state. This act has been fully preserved in the materials of the Ephesus Council, and in fragments of the Theodosian Code (C. Th. 9,45,4) and Justinian Code (I. 1,12,3). This constitution was promulgated in the church near Alexandria, and it may be regarded as taking over imperial legislation into the field of church legislation. Except that it was not announced at the synod and none of the bishops did so and only monks proclaimed the text in their churches. However, after its promulgation in the Theodosian Code, it also became an applicable law in the western part of the empire. ${ }^{14}$

\section{Subjective Scope of confugium ad ecclesias}

The imperial legislation governed in detail the individuals who could benefit from confugium ad ecclesias.

First of all, public debtors were entitled to church asylum (debitores publici), who under the constitution of Theodosius I from 392 could exercise their right to confugium ad ecclesias, if they had paid their debts:

C. Th. 9,45,1 (Imppp. Theodosius, Arcadius et Honorius): Publicos debitores, si confugiendum ad ecclesias crediderint, aut ilico extrahi de latebris oportebit aut pro his ipsos, qui eos occultare probantur, episcopos exigi.

But the obligation to pay debts (most likely overdue taxes) was not imposed on the asylum seeker but on a church clergyman hosting asylum. Such a reservation in practice could prevent the actual use of this institution and became a source of criticism by bishops. The constitution that gave asylum to public debtors was not included in Justinian Code. Subsequently, Christian emperors extended the application of confugium ad ecclesias on Jews:

C. Th. 9,45,2 (Impp. Arcadius et Honorius aa. Archelao praefecto Augustali): Iudaei, qui reatu aliquo vel debitis fatigati simulant se christianae legi velle

${ }^{14}$ Cf. G. Franke, Das Kirchenasyl..., pp. 30-36; K. Burczak, Prawo azylu ..., pp. 74-75. 
coniungi, ut ad ecclesias confugientes vitare possint crimina vel pondera debitorum, arceantur nec ante suscipiantur, quam debita universa reddiderint vel fuerint innocentia demonstrata purgati.

The constitution of Emperor Arcadius established on 17 June 397 concerned Jews declaring the transition to the Christian faith, who protected themselves in Christian temples against criminal liability, most often for tax and financial fraud. The emperor forbade them to grant asylum before fulfilling their obligations.

Other individuals expressis verbis entitled to church asylum were persons dependent on others or seriously addicted to others, for whom they kept the accounts. In the constitution from 398, Emperor Arcadius specifically listed the above categories of people:

C. Th. 9,45,2 (Impp. Arcadius et Honorius aa. Eutychiano praefecto praetorio): Si quis in posterum serous ancilla, curialis, debitor publicus, procurator, murilegulus, quilibet postremo publicis privatisve rationibus involutus ad ecclesiam confugiens vel clericus ordinatus vel quocumque modo a clericis fuerit defensatus nec statim conventione praemissa pristinae condicioni reddatur, decuriones quidem et omnes, quos solita ad debitum munus functio vocat, vigore et sollertia iudicantum ad pristinam sortem velut manu mox iniecta revocentur: quibus ulterius legem prodesse non patimur, quae cessione patrimonii subsecuta decuriones esse clericos non vetabat. Sed etiam hi, quos oeconomos vocant, hoc est qui ecclesiasticas consuerunt tractare rationes, ad eam debiti vel publici vel privati redhibitionem amota dilatione cogantur, in qua eos obnoxios esse constiterit, quos clerici defensandos receperint nec mox crediderint exhibendos.

In the fragment of the imperial constitution cited above, which was criticised by the Synod of Carthage in 399, categories of persons who were subordinate to somebody or were dependent on others were taxatically calculated and could exercise their right to church asylum provided they had paid their debts. The category of those people included a slave man, slave woman, decurion, ${ }^{15}$ public debtor, administrator, fish hunter, or anyone who runs public or private accounts (servus ancilla, curialis, debitor publicus, procurator, murilegulus, quilibet postremo publicis privatisve rationibus

15 C. Th. 12,1,123,1: Evidens etiam praecepto nostro tempus expressum est, ex quo consulatu, si qui de curialibus ad ecclesiam confugissent, omni scirent patrimonio curiae esse cedendum. In the year 391 Emperor Theodosius and Arcadius established the constitution in which they imposed a criminal sanction on decurions for having fled to church. They were to be deprived of property for the benefit of the Senate. 
involutus ad ecclesiam confugiens). If the above-mentioned persons fled to church and were unable to fulfil their obligations, the clergy had to do it instead of them. Another act that referred to individuals authorised to benefit from confugium ad ecclesias was the constitution of Emperor Theodosius from 409 published in Ravenna:

C. 1,12,2 (Imperatores Honorius, Theodosius): Fideli ac devota praeceptione sancimus nemini licere ad sacrosanctas ecclesias confugientes abducere: sub hac videlicet definitione, ut, si quisquam contra hanc legem venire temptaverit, sciat se ad maiestatis crimen esse retinendum.

That constitution extended the protection afforded by the right of asylum to all who took shelter in church, except that this constitution was not included in the Theodosian Code.

In 432, Emperor Theodosius issued another constitution which governed the right of asylum for slaves fleeing to church from the cruelty of their owners:

C. Th. 9,45,5 (Impp. Arcadius et Honorius aa. Hierio praefecto praetorio): Super confugientibus ad sanctae religionis altaria sanctionem in perpetuum valituram credidimus promulgandam, ut, si quidem servus cuiusquam ecclesiam altariave loci tantum veneratione confisus sine ullo telo petierit, is non plus uno die ibidem dimittatur, quin domino eius vel cuius metu poenam imminentem visus est declinasse, a clericis quorum interest nuntietur. Isque eum impertita indulgentia peccatorum, ut nullis residentibus iracundiae menti reliquiis, in honorem loci et eius respectu, ad cuius auxilium convolavit, abducat. [...].

Asylum issues for fugitive slaves were already known in earlier regulations regarding confugium ad statuam. Based on the fragment quoted above, it is plausible to state that a slave admitted to asylum for a period of at least one day could be released to his owner by forgiveness and could be taken back to the owner's home. ${ }^{16}$

The most extensive constitution that governed the right of asylum in church was the constitution from 466 published by Emperor Leo I in Constantinople, which was in force throughout the empire (except Constantinople):

C. 1,12,6 pr. (Imperator Leo): Praesenti lege decernimus per omnia loca valitura (excepta hac urbe regia, in qua nos divinitate propitia degentes, quotiens usus exegerit,

16 W. Mossakowski, Azyl w późnym Cesarstwie Rzymskim..., p. 42. 
invocati singulis causis atque personis praesentanea constituta praestamus) nullos penitus cuiuscumque condicionis de sacrosanctis ecclesiis orthodoxae fidei expelli aut tradi vel protrahi confugas nec pro his venerabiles episcopos aut religiosos oeconomos exigi, quae debeantur ab eis: qui hoc moliri aut facere aut nuda saltim cogitatione atque tractatu ausi fuerint temptare, capitali et ultima supplicii animadversione plectendi sunt. Ex his ergo locis eorumque finibus, quos anteriorum le gum praescripta sanxerunt, nullos expelli aut eici aliquando patimur nec in ipsis ecclesiis reverendis ita quemquam detineri atque constringi, ut ei aliquid aut victualium rerum aut vestis negetur aut requies. ${ }^{17}$

According to the provisions of that constitution, everyone who took shelter in church, for whatever reason, was to be granted asylum. The emperor in the above-quoted passage of the Act referred to earlier legal acts governing confugium ad ecclesias. The legal regulations contained above imposed on bishops the obligation to admit fugitives to church and examine their situation. ${ }^{18}$

Further regulations regarding the subjective scope confugium ad ecclesias were found in Justinian Novella:

Nov. 37,9-10: Privilegia insuper sacrosanctae ecclesiae nostrae Carthaginis Iustinianae omnia condonamus quae metropolitanae civitates et earum antistites habere noscuntur, quae etiam Codici nostro in primo eius libro segregata sacrosanctis ecclesiis

17 Cf. also the rest of the quoted constitution C. 1,12,6,1-6: 1. Sed si quidem ipsi refugae apparent publice et se in sacris locis offerunt quaerentibus conveniendos, ipsi, servata locis reverentia, iudicum quibus subiacent sententiis moneantur, responsum daturi, quale sibi quisque perspexerit convenire. 2. Quod si in finibus ecclesiasticis latitant, religiosus oeconomus seu defensor ecclesiae vel certe, quem his negotiis commodiorem auctoritas episcopalis elegerit, reconditam latentemque personam decenter sine ullo incommodo monitus, intra fines ecclesiae si invenitur, praesentet. 3. Cum autem monitus fuerit in publico privatove contractu actione civili, in eius sit arbitrio sive per se seu, si magis elegerit, instructo sollemniter procuratore directo in eius iudicis, cuius pulsatur sententiis, examine respondere. 4. Sed si hoc facere detractat aut differt, iudiciorum legumque solitus ordo servetur. Itaque si res immobiles possidet, post edictorum sollemnia sententia iudicantis usque ad modum debiti bonorum eius sive praediorum traditio seu venditio celebretur. 5. Quod si res mobiles habet easque extra terminos occultat ecclesiae, sententia iudicantis et exsecutoris sollicitudine perquisitae, quocumque occultantur, erutae pro aequitatis tramite modoque debiti publicis rationibus privatisque proficiant. 6. Sane si intra fines habentur ecclesiae vel apud quemlibet ex clericis absconditae sive depositae fuisse firmantur, studio et providentia viri reverentissimi oeconomi sive defensoris ecclesiae diligentia inquisitae quolibet modo ad sacrosanctam ecclesiam pervenientes proferantur, ut pari aequitatis ordine ex isdem bonis fisco vel rei publicae sive creditoribus et quibuscumque iustis petitoribus ad modum debiti consulatur.

18 W. Mossakowski, Azyl w późnym Cesarstwie Rzymskim..., pp. 46-48. 
suum honorem praestare noscuntur: ut civitas quam nostri numinis cognomine decorandam esse perspeximus imperialibus etiam privilegiis exornata florescat. Confugas etiam, qui ad venerabiles ecclesias et earum fines convolare festinant et suae saluti prospicere, nulli penitus licere sacrilegis manibus ab his abstrahere, sed eos venerabilibus locis debita reverentia perpotiri, nisi tamen homicidae sint vel virginum raptores aut Christianae fidei violatores: illos etenim qui talia facinora committunt nullis esse dignos privilegiis quis non confiteatur?

In novel 37, Emperor Justinian extended the application of the right of asylum to the Church in Carthage. With the proviso that, based on the fragment quoted above, it is plausible to state that persons who could not take advantage of confugium ad ecclesias were killers (homicidae), virgin kidnappers (virginum raptores) and those who offended the Christian faith (Christianae fidei violatores). The recognition of a refugee's right to asylum depended on the examination of the circumstances as to whether a refugee was the perpetrator of criminal offences.

In turn, in the next novella of 542, issues of asylum for adulterers were resolved:

Nov. 117,15,1: Quia vero ita comperiuntur aliqui impii, ut etiam in venerandis domibus praesumant in talibus se misceri sceleribus et ibi de peccatis tractare ubi consueverunt deum timentes peccatorum veniam postulare, iubemus, ut si quis talis inveniatur in locis venerabilibus alienae uxori, de qua in suspicione est, post tres, sicut dictum est, contestationes loqui, licentiam esse eius marito utrasque personas defensori ecclesiae aut aliis clericis tradere, <ut> ad eorum periculum divisi isti serventur, donec iudex hoc cognoscens mittat ad episcopum civitatis, quatenus ei isti tradantur, ut debeant sustinere tormentum secundum leges quae interdicunt adulteros a sanctissimis ecclesiis vindicari, nullam neque in hoc aliam iudice quaerente de adulterio probationem nisi tres, sicut supra diximus, contestationes. His enim tribus contestationibus ostensis omnibus modis illi sicut adulteri punientur. Non enim debent huiusmodi personae in venerabili loco habere munimen, quem ipsi per scelus proprium despexerunt. Nam si eos qui alibi rapinas mulierum aut adulterium committunt et ad orationum domos confugiunt ab eis vindicari nostrae leges non sinunt, quomodo illis qui in ipsa ecclesia tale scelus studuerunt perpetrare permittimus aliquod auxilium ex ecclesiasticis terminis invenire?

The above-mentioned novella was intended to protect the marriage and prevent adultery. The right of asylum did not apply to a man who met a married woman in church. The lovers who were found in church had to be put at the disposal of the bishop and the state authorities. According to 
the emperor, the church is a dignified place and cannot give shelter and protection to people who violate the principles of the Christian faith. ${ }^{19}$

Emperor Justinian issued another law governing the matters of persons who may benefit from confugium ad ecclesias:

Nov. 128,13: Nulli vero penitus liceat publica tributa exigentium neque censualibus aut rationum scriptoribus aut aliis quibusdam publico ministrantibus excusatione quod in loco sacro resideant uti contra eos qui dicunt se laesos ab eis in fiscalium exactione.

In a novella of 545, Justinian granted the right of asylum to public debtors who were unable to pay their tax debts and were harmed by government officials. That category of debtors could have sought shelter in church. ${ }^{20}$

\section{Territorial scope confugium ad ecclesias}

Referring to the territorial extent of the right of asylum, it is plausible to state that after the year 313, an attempt was made to systematise the terms determining the place of asylum. Earlier, the following names templum or aerarium had been used for determining the place where the protection given by the right of temple asylum could have been effective.

In the imperial legislation of that period, there were several laws in which there was a possibility to find the names of the place of church asylum: ${ }^{21}$

C. Th. 9,45,1 (Imppp. Theodosius, Arcadius et Honorius aaa. Romulo comiti sacrarum largitionum): Publicos debitores, si confugiendum ad ecclesias crediderint, aut ilico extrahi de latebris oportebit aut pro his ipsos, qui eos occultare probantur, episcopos exigi.

C. Th. 9,45,2 (Imppp. Impp. Arcadius et Honorius aa. Archelao praefecto Augustali): Iudaei, qui reatu aliquo vel debitis fatigati simulant se christianae legi velle coniungi, ut ad ecclesias confugientes vitare possint crimina vel pondera debitorum, arceantur nec ante suscipiantur, quam debita universa reddiderint vel fuerint innocentia demonstrata purgati.

\footnotetext{
19 More cf. W. Mossakowski, Azyl w późnym Cesarstwie Rzymskim..., pp. 53-55.

20 Cf. C. Th. 12,1,123,1.

${ }^{21}$ Cf. e.g. C. Th. 9,45,3; C. 1,1,12,1; C. 1,12,2.
} 
In the above-quoted fragments of the act of 392, established by Theodosius I and Emperor Arcadius in 397, the phrase ad ecclesias may be found to determine the place of shelter for fugitives. It seems that the term ad ecclesias may be translated as buildings of Christian churches because in that period there were open churches, which replaced earlier closed meetings of Christians in private places. In addition, according to the constitution of 21 November 419, the protection provided by the right of asylum was already at a distance of 50 steps from the church:

Const. Sirmond. 13: Convenit, nostris praescita temporibus ut iustitiam inflectat humanitas. Nam cum plerique vim fortunae saevientis aufugerint adque ecclesiasticae defensionis munimen elegerint, patiuntur inclusi non minorem quam vitavere custodiam: nullis enim temporibus in luce vestibuli eis aperitur egressus. Adque ideo quinquaginta passibus ultra basilicae fores ecclesiasticae venerationis sanctitas inhaerebit. Ex quo loco quisque tenuerit exeuntem, sacrilegii crimen incurrat.

According to the constitution of Emperors Honorius and Theodosius II, contained in Theodosiani libri XVI cum constitutionibus sirmondianis (Każdy kto przekroczyłby linię 50 kroków od Kościoła podlegał crimen sacrilegii) would cross this line of 50 steps, was subject to crimen sacrilegii.

In the above-mentioned constitution of Theodosius, established in 431 (imperial law about refuge in temples), the full text of which has been preserved in the materials of the Ephesus Council, there were also references to the territorial scope confugium ad ecclesias. Other specific solutions also included:

that those taking shelter in the church could not have stayed there for a long period of time, which was a benefit for the clergy, because they had less troublesome when it came to stay of refugees in the temple, places of shelter were designated in church buildings, but not strictly in religious ones, there were houses, gardens, courtyards, baths, cloisters. ${ }^{22}$

Thus, it may be concluded that the place of shelter was extended to places belonging to temples, bishop's houses or monasteries.

Further specification of the term ad ecclesias was made by Emperor Theodosius II in the constitution established in 431: C. Th. 9,45,4 pr (Impp.

22 English translation, http://www.documenta-catholica.eu/d_Concilia \%20-\%20 The $\%$ 20First $\%$ 20Seven $\%$ 20Ecumenical $\% 20$ Councils $\% 20$ [History $\% 20$ and $\% 20$ Canons] $\% 20$ -\%20EN.pdf [access: 30.06.2019]. 
Theodosius et Valentinianus aa. Antiocho pf. p): Pateant summi dei templa timentibus.

The emperor clearly indicates the territorial sextent of asylum in the buildings of Christian temples - Summi Dei templa. ${ }^{23}$

The next constitution of Emperor Theodosius from 432 introduced altars as a place of asylum:

C. Th. 9,45,5 (Imppp. Theodosius, Arcadius et Honorius aa. Hierio praefecto praetorio): Super confugientibus ad sanctae religionis altaria sanctionem in perpetuum valituram credidimus promulgandam, ut, si quidem servus cuiusquam ecclesiam altariave loci tantum veneratione confisus sine ullo telo petierit, is non plus uno die ibidem dimittatur, quin domino eius vel cuius metu poenam imminentem visus est declinasse, a clericis quorum interest nuntietur.

In the quoted fragment of the constitution, which was published in respect of slave escapes, two terms may be found to signify a place where shelter could be sought. Next to the term church (ecclesia) there is the concept of an altar (altaria). Wording "sanctae religionis altaria" and "ecclesiam altariave loci tantum veneratione" indicate that the temples and their altars constituted the place of asylum - with an indication of the inviolability of those places. In turn, Emperor Leon in the constitution established in 466 mentions the Orthodox Temple as a place of asylum:

C. 1,12,6 (Imperator Leo): Praesenti lege decernimus per omnia loca valitura (excepta hac urbe regia, in qua nos divinitate propitia degentes, quotiens usus exegerit, invocati singulis causis atque personis praesentanea constituta praestamus) nullos penitus cuiuscumque condicionis de sacrosanctis ecclesiis orthodoxae fidei expelli aut tradi vel protrahi confugas nec pro his venerabiles episcopos aut religiosos oeconomos exigi, quae debeantur ab eis.

In the analysed fragment, the wording sacrosanctis ecclesiis ecclesiis orthodoxae was used for marking a place of shelter for asylum seekers. It seems that this was the result of the increasing incidence of heretical factions of the public church. Thus, the above legal act was an imperial privilege for the Church recognised by the emperor, by which the right of asylum ${ }^{24}$ was retained.

23 Cf. also C. 1.12.5.

24 More cf. K. Burczak, Prawo azylu..., pp. 74-75; W. Mossakowski, Azyl w późnym Cesarstwie Rzymskim..., pp. 78-79. 


\section{Conclusion}

In summary, it is plausible to state that the idea of church asylum was present in the Roman society and had an impact on the development of asylum law in the Middle Ages. However, trying to answer the question of what new elements the idea of the Christian mercy has brought into the content of the right of asylum (misericordia), it seems that the group of individuals entitled to asylum protection has been extended, based on the moral obligation to help the weak. The territorial extent is also expanded to include places belonging to temples, such as the bishop's house, cemetery and monasteries. An important novelty was the validity of confugium ad ecclesias in every Christian temple because it was not the emperor's decision that ius asylum was in force, and the sanctity of the place. Imperial constitutions only sanctioned the existing state of affairs by introducing legal regulations. Bishops' attempts to govern asylum became the basis for the emperors to issue appropriate constitutions in this respect. However, it seems that imperial constitutions played a more important role in shaping the right of asylum after the year 313 than the synodal legislation regarding asylum.

\section{Bibliography}

Burczak K., Prawo azylu w ustawodawstwie synodów galijskich V-VII wieku, Lublin 2005.

Caron P.G., Asylum, in: Novissimo Digesto Italiano, vol. 1-2, ed. A. Azara, E. Eula, Torino 1957-1958.

Das antike Asyl. Kultische Grundlagen, rechtliche Ausgestaltung und politische Funktion, ed. M. Dreher, Köln-Weimar 2003.

Franke G., Das Kirchenasyl im Kontext sakraler Zufluchtnahmen der Antike. Historische Erscheinungsformen und theologische Implikationen in patristischer Zeit, Frankfurt am Main 2003.

Gioffredi C., Ad statuas confugere, Studia et Documenta Historiae et Iuris 1946, vol. 12. Grifò G., Asilo, in: Enciclopedia del diritto, vol. 3, ed. F. Calasso, [Milano] 1958.

Heumann H.G., E. Seckel, Handlexikon zu den Quellen des römischen Rechts, Jena 1907 (reprint Graz 1958).

Holleaux M., Remarques sur les décrets des villes de Crète relatifs à l asylia de Téos, Klio 1913, vol. 13. 
Ihne W., The Asylum of Romulus, The Classical Museum, A Journal of Philology, and of Ancient History and Literature 1846, vol. 3.

Karlin-Hayter P., Aréthas et le droit d'asile. A propos d'un article récent, Byzantion 1964, vol. 34, no. 2.

Kulbat H., Azyl kościelny. Studium prawno-historyczne, Łomża 1938.

Manfredini A.D., "Ad ecclesiam confugere", "ad statuas confugere" nell'età di Teodosio I, in: Atti dell'Accademia Romanistica Costantiniana, vol. 6. Convegno internazionale, ed. G. Crifò, Perugia 1986.

Mossakowski W., Azyl kościelny a problem religii w późnym Cesarstwie Rzymskim, in: Profesorowi Janowi Kodrębskiemu in memoriam, ed. A. Pikulska-Robaszkiewicz, Łódź 2000.

Mossakowski W., Azyl w późnym Cesarstwie Rzymskim (confugium ad statuas, confugium ad ecclesias), Torun 2000.

Mossakowski W., Karalność naruszenia azylu Kościoła w epoce cesarstwa rzymskiego, in: Kara śmierci w starożytnym Rzymie, ed. H. Kowalski, M. Kuryłowicz, Lublin 1996.

Mossakowski W., The Problems of the Temple Asylum Genesis in the Ancient Rome, Pomoerium. Studia et Commentarii ad Orbem Classicum Spectantia 1996, vol. 2.

Mossakowski W., Z badań nad prawem azylu w starożytności chrześcijańskiej, Prawo Kanoniczne 1996, vol. 39, no. 1/2.

Sondel J., Słownik łacińsko-polski dla prawników i historyków, Kraków 1997.

Stengel P., Asylum, in: Thesaurus Linquae Latinae, vol. 2, Leipzig 1900-1906.

Śrutwa J., Praktyka azylu kościelnego w ujęciu św. Augustyna, in: Chrześcijanie a życie publiczne w Cesarstwie Rzymskim III-IV w., ed. J. Śrutwa, Lublin 1988.

Woeß F. v., 'Aavdia [online], Zeitschrift der Savigny-Stiftung für Rechtsgeschichte: Romanistische Abteilung 1926, vol. 46, no. 1, https:/ /www.degruyter. com/view/j/zrgr.1926.46.issue-1/zrgra.1926.46.1.32/ zrgra.1926.46.1.32. xml?format=INT [access: 1.07.2020].

Żurek A., Wprowadzenie do Ojców Kościoła, Kraków 1993.

\section{Sum mary}

Beginnings of asylum (asylum, ius asyli, confugium) in ancient Rome dates back to Romulus times. In subsequent periods of the development of the Roman state, the right of asylum was further developed and included in the norms of material and legal nature. In the Republic Period there were no comprehensive legal regulations regarding ius asyli, although temple asylum was known. It was only during the empire that legal regulation of asylum was in place and two of its forms were developed, confugium ad statuum (asylum, escape to the monument to the emperor) and confugium ad ecclesias (church asylum). That study focuses on answering the question of whether Christian ideas had an impact on the subjective 
and territorial scope confugium ad ecclesias. After the Edict of Milan in the year 313, Christianity, being able to worship publicly, began to influence the consciousness of the inhabitants of the empire. The Church was conceived as an institution protecting the weak, persecuted and those in need. The right of asylum was also enriched with some Christian elements, especially mercy (misericordia), in relation to individuals entitled to benefit from asylum protection. The territorial extent is also expanded to include places belonging to temples, such as the bishop's house, cemetery and monasteries. An important novelty was the validity of confugium ad ecclesias in every Christian temple because it was not the emperor's decision that was in force of ius asylum and the sanctity of the place. However, imperial constitutions played a more important role in shaping the right of asylum in the $4^{\text {th }}$ and $5^{\text {th }}$ centuries than the synodal legislation.

Key words: asylum, confugium ad ecclesias, Roman law, temples

\section{ZAKRES PODMIOTOWY I TERYTORIALNY CONFUGIUM AD ECCLESIAS A IDEE CHRZEŚCIJAŃSKIE}

\section{Streszczenie}

Początki azylu (asylum, ius asyli, confugium) w starożytnym Rzymie sięgają już czasów Romulusa. W kolejnych okresach rozwoju państwa rzymskiego następował dalszy rozwój prawa azylu i ujmowanie go w normy natury materialnoprawnej. W okresie republiki nie było wprawdzie kompleksowych regulacji prawnych odnośnie do ius asyli, chociaż znany był azyl świątynny. Dopiero w okresie cesarstwa nastąpiło prawne uregulowanie asylum, wykształcone zostały dwie jego formy: confugium ad statuum (azyl, ucieczka do pomniku cesarza) oraz confugium ad ecclesias (azyl kościelny). W niniejszym opracowaniu skupiono się na odpowiedzi na pytanie, czy idee chrześcijańskie miały wpływ na podmiotowy oraz terytorialny zakres confugium ad ecclesias. Po edykcie mediolańskim w 313 r. chrześcijaństwo, mogąc sprawować kult publicznie, zaczęło wpływać na świadomość mieszkańców imperium. Kościół był pojmowany jako instytucja chroniąca słabszych, prześladowanych i potrzebujących. Także prawo azylu zostało wzbogacone o pewne elementy chrześcijańskie, zwłaszcza o miłosierdzie (misericordia), w odniesieniu do podmiotów uprawnionych do korzystania z ochrony, jaką dawał azyl. Także zakres terytorialny ulega rozszerzeniu o miejsca przynależące do świątyń, takie jak dom biskupa, cmentarz i klasztory. Istotną nowością było obowiązywanie confugium ad ecclesias w każdej świątyni chrześcijańskiej, ponieważ to nie decyzja cesarza sprawiała, że obowiązywało ius asylum, a świętość miejsca. 
Jednakże w kształtowaniu się prawa azylu w IV i V w. ważniejszą rolę odgrywały konstytucje cesarskie, niż ustawodawstwo synodalne.

Słowa kluczowe: azyl, confugium ad ecclesias, prawo rzymskie, świątynie

\section{СУБЪЕКТИВНАЯ И ТЕРРИТОРИАЛЬНАЯ СФЕРА CONFUGIUM AD ECCLESIAS И ХРИСТИАНСКИЕ ИДЕИ}

\section{Резюме}

Истоки убежища (asylum, ius asyli, confugium) в древнем Риме относятся еще ко времени Ромула. В последующие периоды развития римского государства закон об убежище продолжал развиваться, и был включен в нормы материально-правового характера. Во времена республики не было комплексных правовых норм относительно ius asyli, хотя было известно храмовое убежище. Лишь во время империи asylum было юридически регламентировано, были образованы две его формы: confugium ad statuum (убежище, побег к памятнику императора) и confugium ad ecclesias (церковное убежище). Это исследование посвящено ответу на вопрос о том, повлияли ли христианские идеи на субъективную и территориальную сферу confugium ad ecclesias. После Миланского эдикта в 313 году христианство, получившее возможность публично справлять культ, стало влиять на сознание жителей империи. Церковь понималась как институт защиты слабых, преследуемых и нуждающихся. Кроме того, право убежища было обогащено некоторыми христианскими элементами, особенно милосердием (misericordia), в отношении лиц, имеющих право на защиту, предлагаемую убежищем. Кроме того, территориальный охват был расширен и включал места, принадлежащие храмам, такие как дом епископа, кладбище и монастыри. Важным нововведением было действие confugium ad ecclesias в каждом христианском храме, поскольку не императорское решение делало обязательным ius asylum, а святость этого места. Однако в формировании права на убежище в IV и V веках более важную роль играли императорские конституции, чем синодальное законодательство.

Ключевые слова: убежище, confugium ad ecclesias, римское право, храмы 
